\title{
Beta-adrenergic receptors are expressed across diverse cancers
}

\author{
Steven L. Rains ${ }^{1}$, Clarissa N. Amaya ${ }^{1}$ and Brad A. Bryan ${ }^{1}$ \\ ${ }^{1}$ Department of Biomedical Sciences, Texas Tech University Health Sciences Center, El Paso, TX, USA \\ Correspondence to: Brad A. Bryan, email: brad.bryan@ttuhsc.edu \\ Keywords: beta adrenergic, beta blocker, cancer \\ Received: May 12, $2017 \quad$ Accepted: June 23, $2017 \quad$ Published: August 23, 2017 \\ Copyright: Rains et al. This is an open-access article distributed under the terms of the Creative Commons Attribution License 3.0 \\ (CC BY 3.0), which permits unrestricted use, distribution, and reproduction in any medium, provided the original author and source \\ are credited.
}

\section{ABSTRACT}

Based largely on retrospective analyses and a handful of prospective case reports, pharmacological inhibition of the beta adrenergic receptors using beta blockers has shown clinical anti-cancer efficacy in reproductive cancers, as well as angiosarcoma and multiple myeloma. Because of the potential promise of beta blockers as an adjunct to standard anti-cancer therapy, it is imperative to identify other tumor types expressing beta adrenergic ( $\beta-A R)$ receptors so future preclinical and clinical studies can be directed at the most promising tumor targets. We performed immunohistochemical detection of $\beta 1-A R, \beta 2-A R$, and $\beta 3-A R$ across 29 of the most common human cancer types (389 tissues total) and 19 matching nondiseased controls ( 100 tissues total). Our analysis revealed all three $\beta$-AR receptors were expressed most strongly in melanoma relative to other cancer types. Other malignancies that revealed relatively higher levels of $\beta$-AR receptors were esophagus, pancreas, kidney, and lung cancers. Moreover, particular $\beta$-AR receptors exhibited significant overexpression in tumor tissue relative to their matching normal tissue in urogenital/reproductive malignancies including breast, endometrium, ovarian, and urothelial cancer, as well as colon, lung, and thyroid cancer. This study identifies several cancer types expressing the $\beta$-AR receptors which should be evaluated in future studies for susceptibility to beta blockade.

\section{INTRODUCTION}

Beta adrenergic $(\beta-A R)$ receptors are G-protein coupled receptors responsible for mediating vasodilation following stimulation by the catecholamines epinephrine and norepinephrine $[1,2]$. When activated, the $\beta$-AR receptors induce intracellular signal transduction pathways through triggering cyclic adenosine monophosphate (cAMP) and cAMP-dependent protein kinase A cascades $[1,2]$. This leads to endothelial nitric oxide synthase (NOS)-mediated release of nitric oxide to induce vasodilation and synthesis of pro-angiogenic factors such as vascular endothelial growth factor and basic fibroblast growth factor to promote angiogenesis $[1,2]$.

Three different $\beta$-AR receptors have been identified in humans, and are widely expressed in vascular tissues [2-5]. $\beta$-AR1 receptors are primarily expressed in cardiac tissue where they perform vital roles in regulating cardiac output, and additional expression has been detected in the urinary bladder and cerebral cortex [6]. $\beta$-AR2 receptors are expressed at high density in the lung on bronchial smooth muscles, bronchial epithelial cells, and multiple immune cells $[7,8]$. $\beta$-AR3 is abundant in brown adipose tissue and performs significant roles in lipolysis and thermogenesis [9].

The $\beta$-AR signaling pathway drives the pathogenesis of the benign vascular tumor infantile hemangioma $[10,11]$ and several malignant tumor types including angiosarcoma [12-16], breast cancer [17], and ovarian cancer [18]. Pharmacological inhibition of the $\beta-A R$ receptors with beta blockers has shown clinical efficacy against infantile hemangiomas and angiosarcomas [10, 12-15, 19] and based on retrospective studies of large patient cohorts, beta blockers contribute to improving 
overall survival and decreasing tumor proliferation across a several common cancer types [17, 18, 20-22]. Due to these findings, in late 2016 the beta blocker propranolol was assigned Orphan Drug Designation in Europe for use in soft tissue sarcomas. With promises of a potentially low cost adjuvant therapy for certain cancers, it is imperative to determine if other more common cancers express the $\beta$-AR receptors, and thus could be clinically susceptible to beta blockade.

To accomplish this, we determined the expression of $\beta$-AR $1, \beta$-AR2, and $\beta$-AR3 receptors across 29 tumor types representing the most common cancers found in humans and 19 matching normal tissues using high density tissue microarrays. The knowledge gained from this study will allow researchers and clinicians to efficiently target the most promising cancer types that express the $\beta$-AR receptors.

\section{RESULTS}

Numerous studies have examined the expression of the $\beta$-AR receptors primarily in the heart, lung, and vascular tissues due to the effects of beta blockers on these tissues [23]. Interestingly, new databases such as GTEx Portal (www.gtexportal.org), BioGPS (www.biogps. org), and the Human Protein Atlas (www.proteinatlas. org) reveal that $\beta$-AR mRNA and protein are surprisingly expressed at variable levels across a large number of normal and diseased tissues.

We analyzed the expression of $\beta$-AR proteins across 19 normal tissues comprising epithelial, mesenchymal, and hematopoietic lineages (Figure 1). Relatively higher expression of $\beta 1-A R$ protein was found in brain, pancreas, and thyroid (Figure 1A); $\beta 2-\mathrm{AR}$ was highest in pancreas, stomach, and thyroid (Figure 1B); and $\beta 3$-AR was highest in colon, kidney, lymph nodes, pancreas, skin, and stomach (Figure 1C). Many normal tissues expressed little to no $\beta$-AR receptors, including colon, esophagus, lung, ovary, skeletal muscle and uterus for $\beta 1$-AR; bladder, lymph node, skeletal muscle, uterus, and ovary for $\beta 2$ AR; and bladder, skeletal muscle, and ovary for $\beta 3-A R$. Representative images of $\beta$-AR staining across selected normal tissues is shown in Figure 1D-1F.

Within cancer tissues, $\beta 1-\mathrm{AR}$ was detected most highly in pancreas adenocarcinoma, melanoma, lung adenocarcinoma, clear cell carcinoma, and esophagus adenocarcinoma (Figure 2). $\beta 2-\mathrm{AR}$ was detected most highly in pancreas adenocarcinoma, melanoma, and lung adenocarcinoma (Figure 3). $\beta 3$-AR was detected most highly in melanoma, and moderate levels of staining were observed across numerous cancer tissues (Figure 4 ), though the higher levels of $\beta 3$-AR staining could be attributed to a relatively high affinity of the antibody to its antigen. Across all cancer tissues tested, melanoma exhibited the highest level of $\beta$-AR receptor expression.
To evaluate if the $\beta$-AR receptors are overexpressed in any of the cancers analyzed in this study, we performed the Mann-Whitney rank sum test to compare IHC scores between normal and cancer tissues. Using a very strict statistical cutoff $(\mathrm{p}<0.01)$, we identified a number of cancers that exhibited overexpression for individual $\beta$-AR receptors (Table 1). Interestingly, urogenital/reproductive cancers including breast, endometrium, ovarian, and urothelial cancers were overrepresented tumors exhibiting $\beta$-AR receptor overexpression.

\section{DISCUSSION}

In this study we evaluated the protein expression of the three $\beta$-AR receptors across a large panel of normal and cancer tissues, showing that these proteins are absent to weakly expressed across many tissues, with moderate to strong expression observed in select tissues. We additionally discovered that the $\beta$-AR receptors were overexpressed in several cancer types, particularly in urogenital and reproductive tumors. Although IHC detection of the $\beta$-AR receptors is not necessarily indicative of the level of tumor responsiveness to $\beta$-blockade, it does help identify $\beta$-AR positive cancers that may benefit from this emerging treatment, while excluding cancers from future studies that do not express these receptors.

The $\beta$-AR receptors are expressed in normal vessels [2-5] and have more recently been detected in various vascular tumors including hemangiomas, hemangioendotheliomas, and angiosarcomas $[13,16$, $24,25]$. Indeed, beta blockade has shown remarkable efficacy in numerous clinical settings against infantile hemangiomas $[10,19]$, hemangioendothelioma [2628 ], and angiosarcoma [12-15]. Due to the success of propranolol against angiosarcoma, this drug has recently received Orphan Drug Designation by the European Medicines Agency for use against soft tissue sarcomas.

In this study we demonstrated that the $\beta$-AR receptors are expressed across multiple cancers, thus it is possible that beta blockade could show efficacy against additional tumor types. Indeed, retrospective studies of individuals taking beta blockers have revealed remarkably improved survival outcomes for patients with multiple cancer types [18, 20, 22], decreased cancer recurrence in stage II breast cancer patients [21], and decreased tumor proliferation rates in stage I breast cancer patients [17]. Due to these findings, a number of clinical trials testing the efficacy of propranolol as an anticancer agent are currently ongoing. The benefit of this report lies in identifying cancer types that express the $\beta$-AR receptors which are most likely to benefit from beta blockade therapy, and to potentially exclude tumor types which do not express $\beta$-AR receptors and likely would show no benefit from beta blockade. Based 

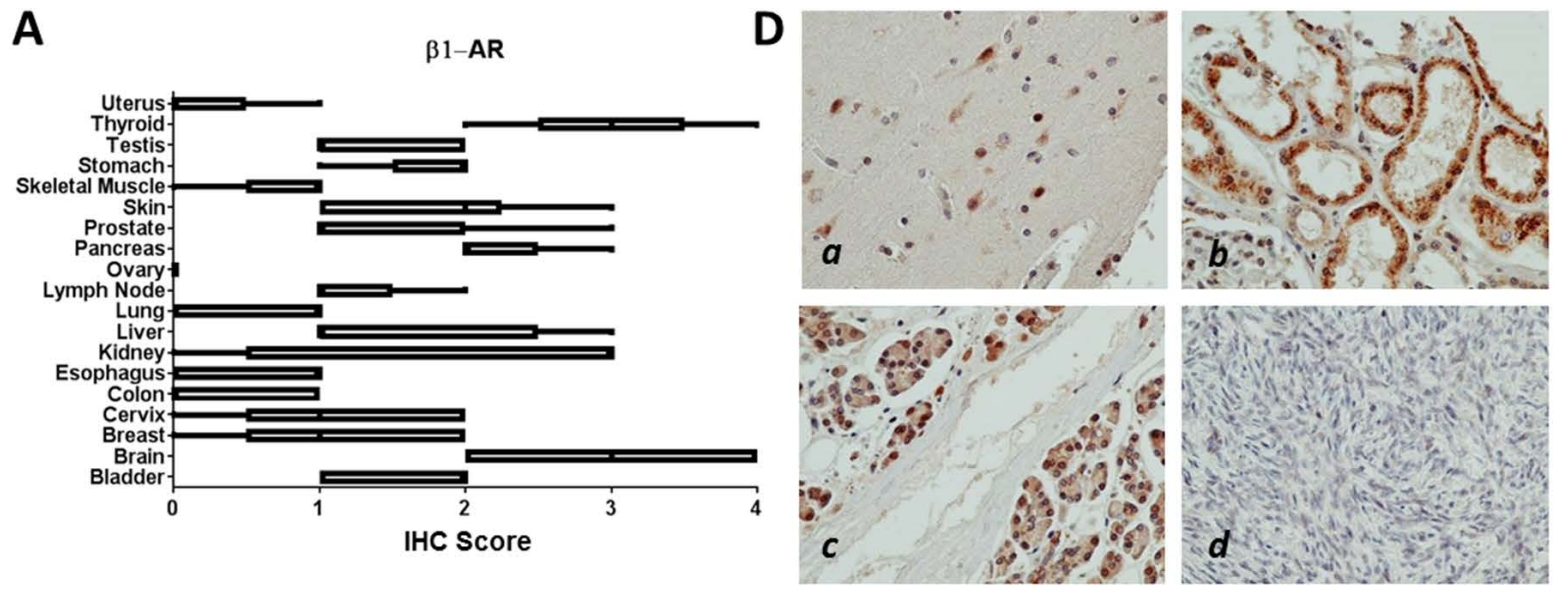

B

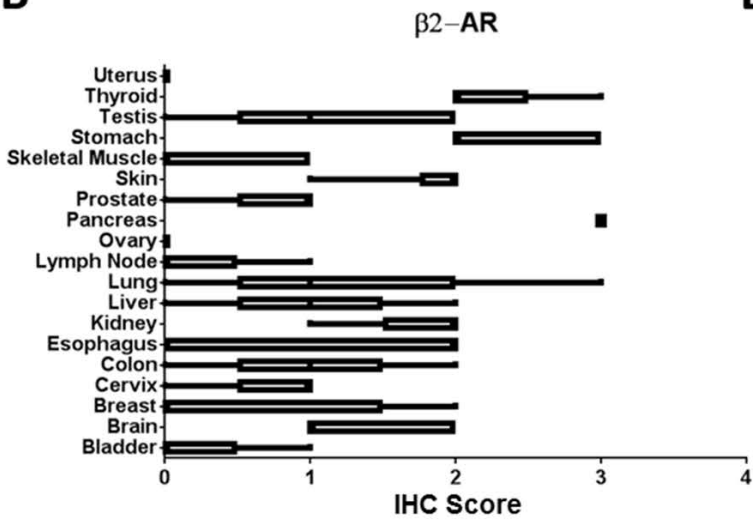

$\mathbf{E}$
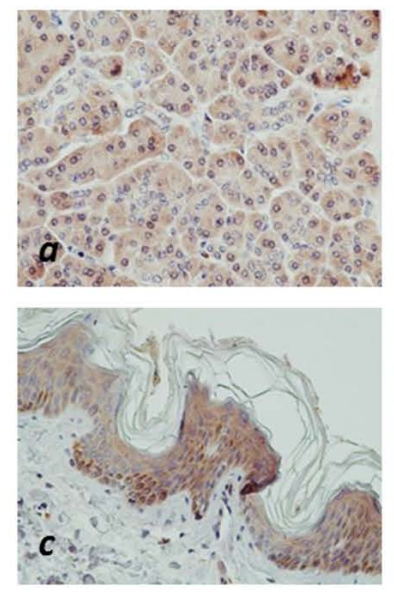
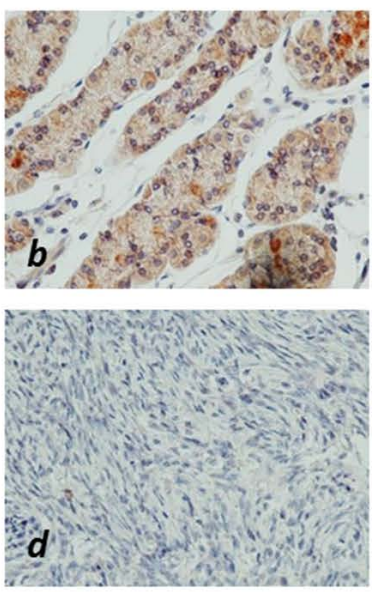

C

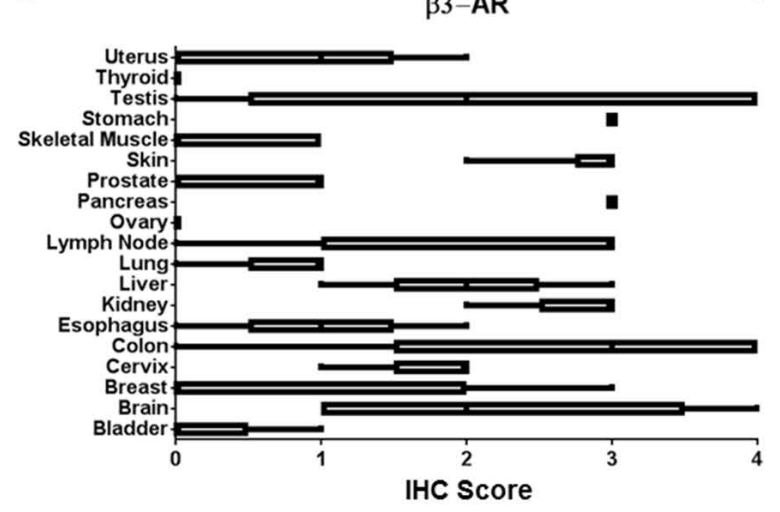

$\mathbf{F}$

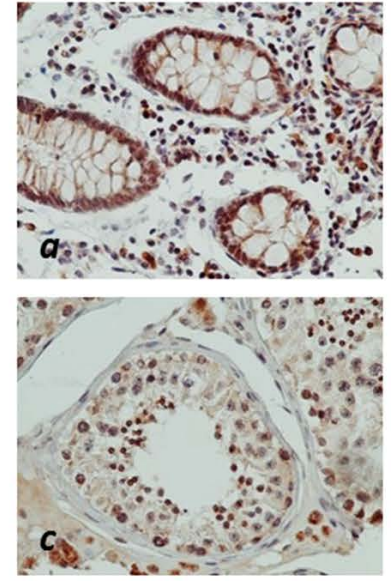

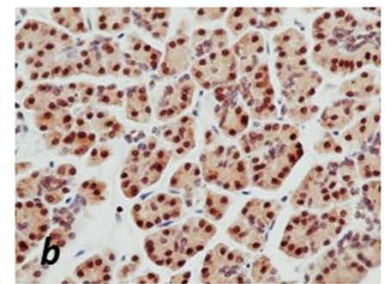

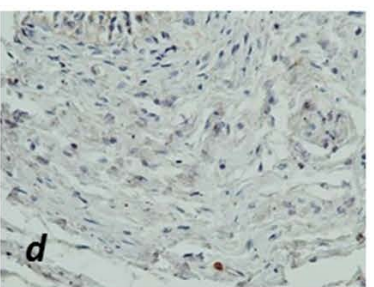

Figure 1: $\boldsymbol{\beta}$-AR receptor protein expression in normal tissues. (A-C) Bar and whiskers plots of IHC staining for $\beta 1$-AR (A), $\beta 2$ $A R(B)$, and $\beta 3$-AR (C) across 19 normal human tissues. The staining intensity was evaluated using the following criteria: $0=$ undetectable staining, $1=$ equivocal/diffuse staining, $2=$ weak staining, $3=$ moderate staining, and $4=$ strong staining. (D) Representative images of relatively higher $\beta 1$-AR staining in brain $(a)$, kidney $(b)$, and pancreas $(c)$, and no staining in ovary $(d)$. (E) Representative images of relatively higher $\beta 2$-AR staining in pancreas $(a)$, stomach $(b)$, and skin $(c)$, and no staining in ovary $(d)$. (F) Representative images of relatively higher $\beta 3$-AR staining in colon $(a)$, pancreas $(b)$, and testis $(c)$, and no staining in bladder $(d)$. 


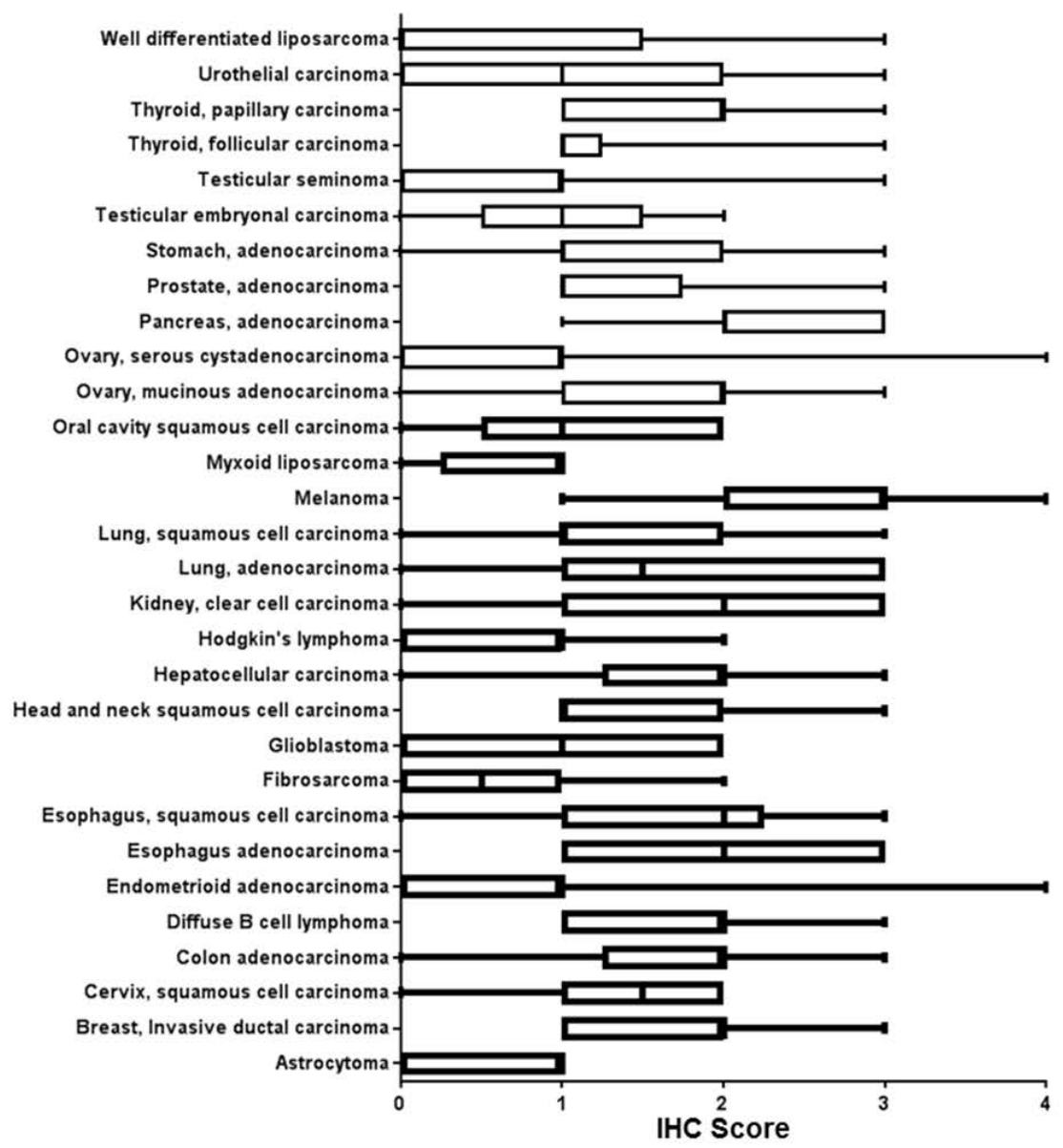

B
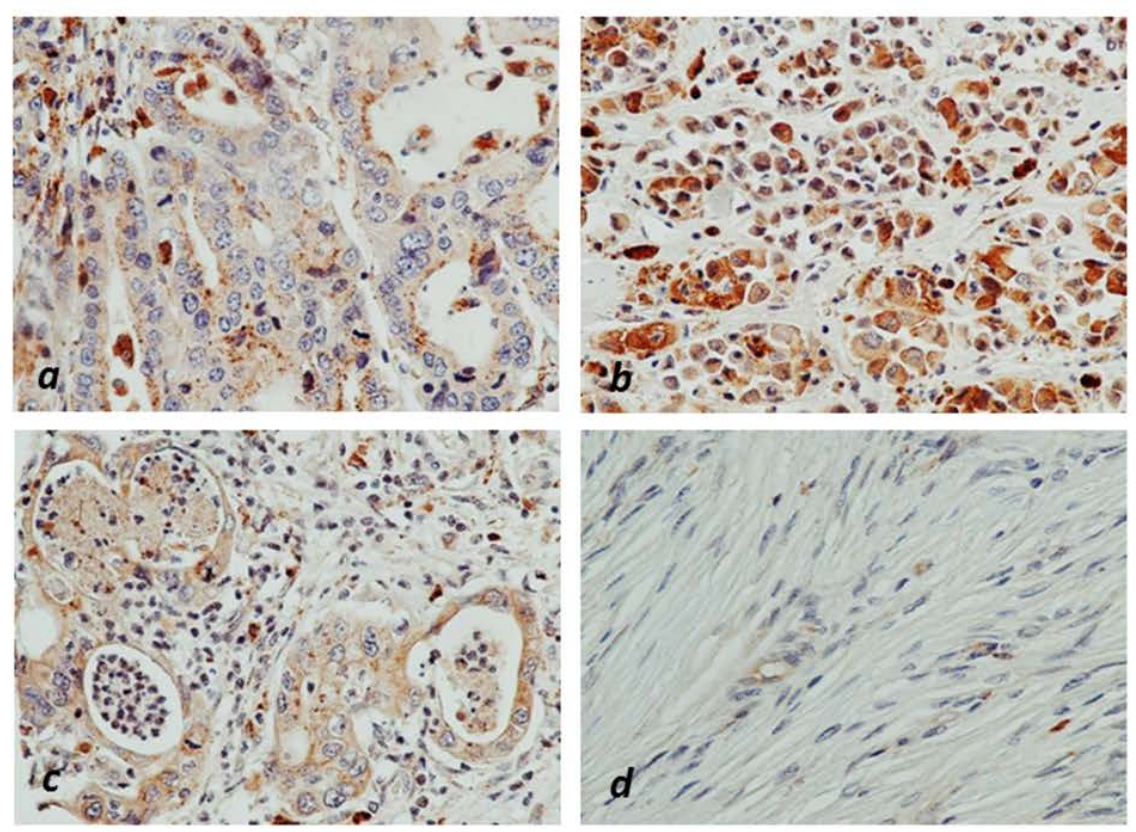

Figure 2: $\beta 1-A R$ receptor protein expression in cancer tissues. (A) Bar and whiskers plots of IHC staining for $\beta 1-A R$ across 29 human cancer types. The staining intensity was evaluated using the following criteria: $0=$ undetectable staining, $1=$ equivocal/diffuse staining, 2 = weak staining, 3 = moderate staining, and $4=$ strong staining. (B) Representative images of $\beta 1$-AR staining in esophagus adenocarcinoma $(a)$, melanoma $(b)$, and pancreas adenocarcinoma $(c)$, and little/no staining in fibrosarcoma $(d)$. 


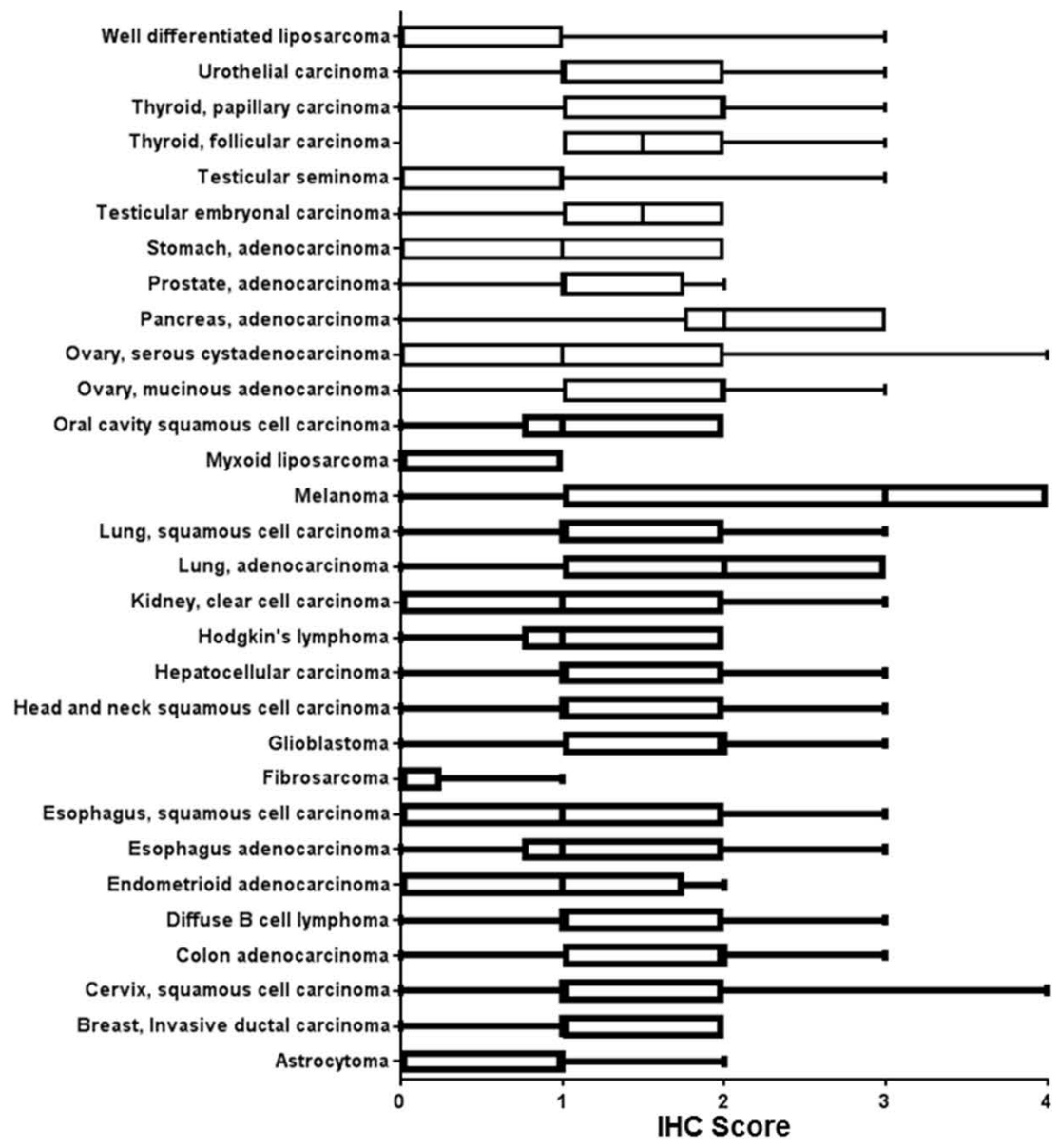

B
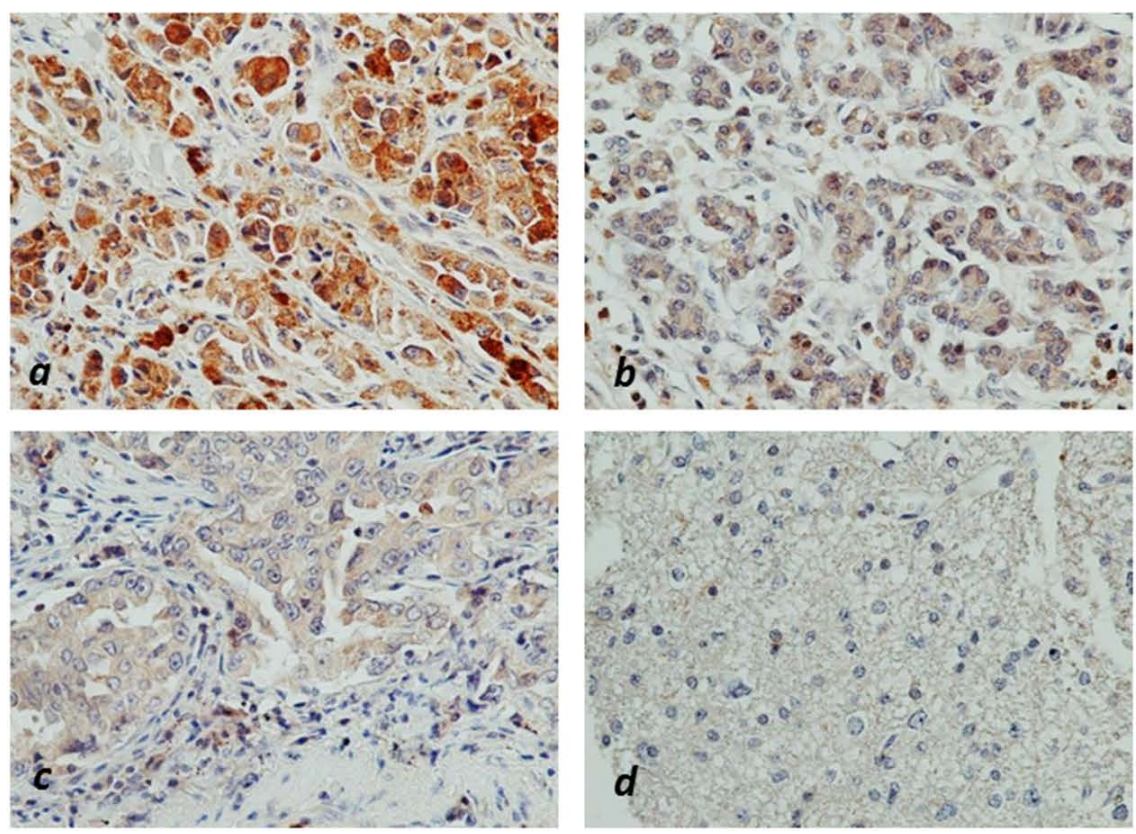

Figure 3: $\beta 2-A R$ receptor protein expression in cancer tissues. (A) Bar and whiskers plots of IHC staining for $\beta 2-A R$ across 29 human cancer types. The staining intensity was evaluated using the following criteria: $0=$ undetectable staining, $1=$ equivocal/diffuse staining, 2 = weak staining, 3 = moderate staining, and $4=$ strong staining. (B) Representative images of $\beta 2$-AR staining in melanoma $(a)$, pancreatic adenocarcinoma $(b)$, and lung adenocarcinoma $(c)$, and little/no staining in astrocytoma $(d)$. 


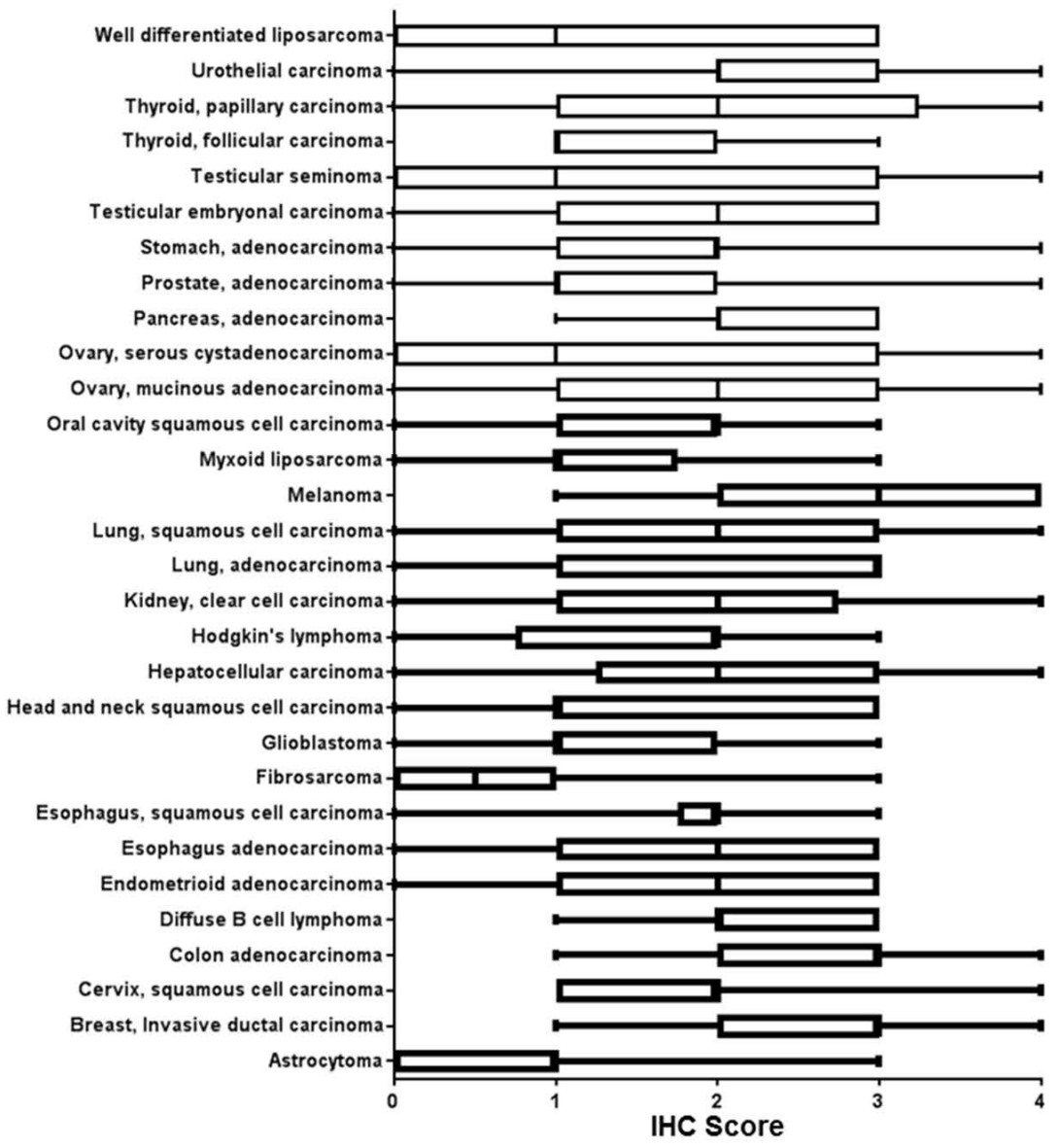

B
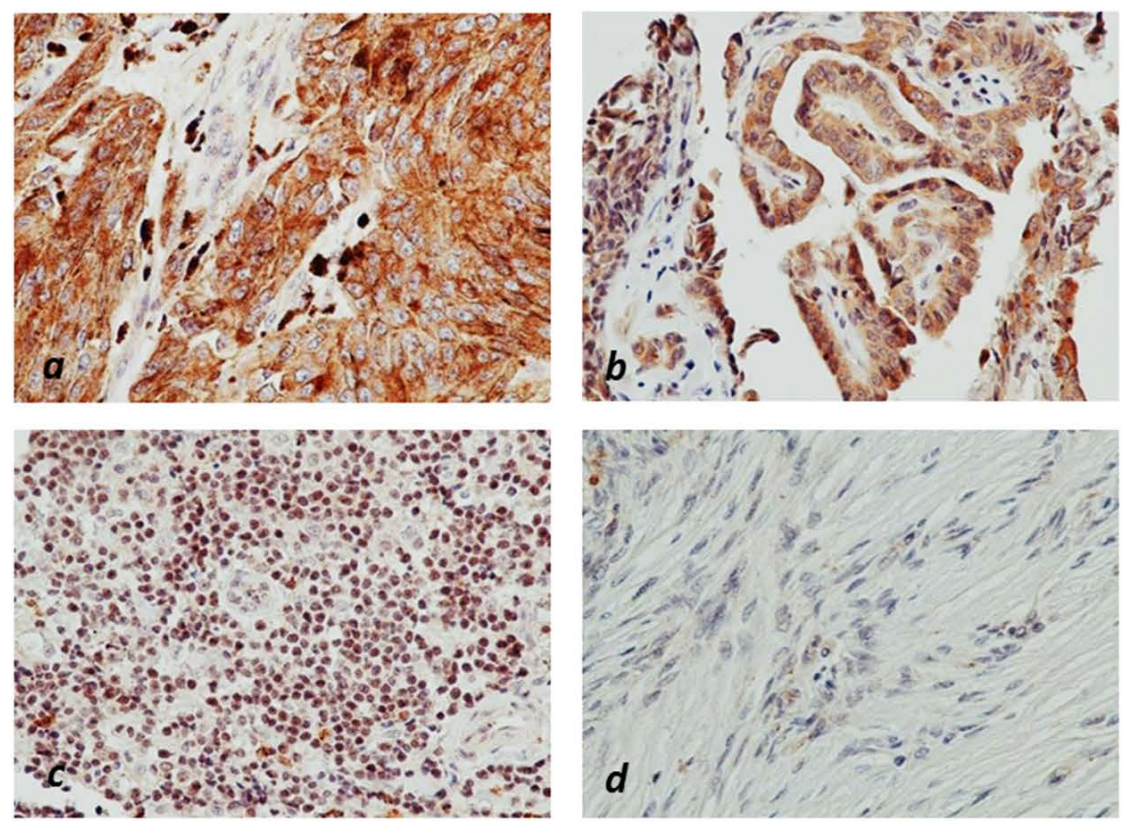

Figure 4: $\beta 3-A R$ receptor protein expression in cancer tissues. (A) Bar and whiskers plots of IHC staining for $\beta 3$-AR across 29 human cancer types. The staining intensity was evaluated using the following criteria: $0=$ undetectable staining, $1=$ equivocal/diffuse staining, 2 = weak staining, $3=$ moderate staining, and $4=$ strong staining. (B) Representative images of $\beta 3$-AR staining in melanoma $(a)$, thyroid papillary carcinoma $(b)$, and diffuse B-cell lymphoma $(c)$, and little/no staining in fibrosarcoma $(d)$. 
Table 1: Overexpression of $\beta$-AR receptors in cancer

\begin{tabular}{lcc}
\hline Tissue type & IHC score normal vs cancer & p value \\
\hline$\beta 1$-AR & 0.4 vs 1.9 & 0.001 \\
Colon adenocarcinoma & & \\
$\beta 2$-AR & 0.0 vs 1.1 & 0.01 \\
Endometrioid adenocarcinoma & 0.0 vs 1.6 & $<0.001$ \\
Ovary mucinous adenocarcinoma & 0.2 vs 1.3 & 0.01 \\
Urothelial carcinoma & & \\
$\beta 3-A R$ & 0.8 vs 3.0 & 0.005 \\
Breast invasive ductal carcinoma & 0.8 vs 2.7 & 0.01 \\
Lung squamous cell carcinoma & 0.0 vs 2.4 & $<0.001$ \\
Ovary mucinous adenocarcinoma & 0.0 vs 1.9 & $<0.001$ \\
Ovary serous cystadenocarcinoma & 0.0 vs 1.9 & $<0.001$ \\
Thyroid follicular carcinoma & 0.0 vs 2.7 & $<0.001$ \\
Thyroid papillary carcinoma & 0.2 vs 2.2 & $<0.001$ \\
Urothelial cancer & &
\end{tabular}

IHC scores are presented as the median score for each tissue type.

$\mathrm{p}$ value $<0.01(\mathrm{CI}=95)$ was considered statistically significant.

Table 2: Clinicopathological features of patient tissue samples

\begin{tabular}{lccc}
\hline Pathology & Sample \# & Median Age & Sex \\
\hline Normal Tissues & & & $4 \mathrm{M} ; 1 \mathrm{~F}$ \\
Bladder & 5 & 33.2 & $4 \mathrm{~F} ; 1 \mathrm{M}$ \\
Brain & 5 & 36.8 & $5 \mathrm{~F}$ \\
Breast & 5 & 42.8 & $5 \mathrm{~F}$ \\
Cervix & 5 & 48.8 & $5 \mathrm{M}$ \\
Colon & 5 & 31.8 & $4 \mathrm{M} ; 1 \mathrm{~F}$ \\
Esophagus & 5 & 32.4 & $4 \mathrm{M} ; 1 \mathrm{~F}$ \\
Kidney & 5 & 35.8 & $4 \mathrm{M} ; 1 \mathrm{~F}$ \\
Liver & 5 & 38.8 & $2 \mathrm{M} ; 2 \mathrm{~F}$ \\
Lung & 5 & 34.8 & $3 \mathrm{M} ; 2 \mathrm{~F}$ \\
Lymph node & 5 & 32.0 & $5 \mathrm{~F}$ \\
Ovary & 5 & 36.8 & $4 \mathrm{M} ; 1 \mathrm{~F}$ \\
Pancreas & 5 & 33.6 & $5 \mathrm{M}$ \\
Prostate & 5 & 34.2 & $6 \mathrm{M} ; 4 \mathrm{~F}$ \\
Skin & 10 & 32.6 & $5 \mathrm{M}$ \\
Skeletal Muscle & 5 & 37.4 & $4 \mathrm{M} ; 1 \mathrm{~F}$ \\
Stomach & 5 & 28.2 & $5 \mathrm{M}$ \\
Testis & 5 & 40.6 &
\end{tabular}

(Continued) 


\begin{tabular}{|c|c|c|c|}
\hline Pathology & Sample \# & Median Age & Sex \\
\hline Thyroid & 5 & 32.6 & $3 \mathrm{M} ; 2 \mathrm{~F}$ \\
\hline Uterus & 5 & 23.6 & $5 \mathrm{~F}$ \\
\hline \multicolumn{4}{|l|}{ Cancer Tissues } \\
\hline Astrocytoma & 9 & 35.2 & $4 \mathrm{M} ; 6 \mathrm{~F}$ \\
\hline Breast, Invasive ductal carcinoma & 20 & 51.1 & $20 \mathrm{~F}$ \\
\hline Cervix, squamous cell carcinoma & 20 & 44.0 & $20 \mathrm{~F}$ \\
\hline Colon adenocarcinoma & 20 & 52.9 & $12 \mathrm{M} ; 8 \mathrm{~F}$ \\
\hline Diffuse B cell lymphoma & 9 & 44.7 & $3 \mathrm{M} ; 6 \mathrm{~F}$ \\
\hline Endometrioid adenocarcinoma & 20 & 54.7 & $20 \mathrm{~F}$ \\
\hline Esophagus adenocarcinoma & 10 & 62.6 & $9 \mathrm{M} ; 1 \mathrm{~F}$ \\
\hline Fibrosarcoma & 10 & 35.1 & $4 \mathrm{M} ; 6 \mathrm{~F}$ \\
\hline Glioblastoma & 11 & 48.9 & $6 \mathrm{M} ; 5 \mathrm{~F}$ \\
\hline Head and neck squamous cell carcinoma & 15 & 63.1 & $12 \mathrm{M} ; 3 \mathrm{~F}$ \\
\hline Hepatocellular carcinoma & 20 & 52.0 & $16 \mathrm{M} ; 4 \mathrm{~F}$ \\
\hline Hodgkin's lymphoma & 10 & 30.1 & $9 \mathrm{M} ; 1 \mathrm{~F}$ \\
\hline Kidney, clear cell carcinoma & 20 & 56.1 & $16 \mathrm{M} ; 4 \mathrm{~F}$ \\
\hline Lung, adenocarcinoma & 10 & 56.7 & $7 \mathrm{M} ; 3 \mathrm{~F}$ \\
\hline Lung, squamous cell carcinoma & 10 & 55.6 & $9 \mathrm{M} ; 1 \mathrm{~F}$ \\
\hline Melanoma & 20 & 55.8 & $14 \mathrm{M} ; 6 \mathrm{~F}$ \\
\hline Myxoid liposarcoma & 4 & 53.5 & $2 \mathrm{M} ; 2 \mathrm{~F}$ \\
\hline Oral cavity squamous cell carcinoma & 5 & 49.4 & $4 \mathrm{M} ; 1 \mathrm{~F}$ \\
\hline Ovary, mucinous adenocarcinoma & 9 & 44.0 & $9 \mathrm{~F}$ \\
\hline Ovary, serous cystadenocarcinoma & 11 & 45.0 & $11 \mathrm{~F}$ \\
\hline Pancreas, adenocarcinoma & 20 & 55.3 & $12 \mathrm{M} ; 8 \mathrm{~F}$ \\
\hline Prostate, adenocarcinoma & 20 & 70.5 & $20 \mathrm{M}$ \\
\hline Stomach adenocarcinoma & 20 & 56.1 & $17 \mathrm{M} ; 3 \mathrm{~F}$ \\
\hline Testicular embryonal carcinoma & 5 & 27.6 & $5 \mathrm{M}$ \\
\hline Testicular seminoma & 15 & 42.4 & $15 \mathrm{M}$ \\
\hline Thyroid, follicular carcinoma & 10 & 50.5 & $1 \mathrm{M} ; 9 \mathrm{~F}$ \\
\hline Thyroid, papillary carcinoma & 10 & 41.6 & $2 \mathrm{M} ; 8 \mathrm{~F}$ \\
\hline Urothelial carcinoma & 20 & 59.8 & $15 \mathrm{M} ; 5 \mathrm{~F}$ \\
\hline Well differentiated liposarcoma & 6 & 51.5 & $4 \mathrm{M} ; 2 \mathrm{~F}$ \\
\hline
\end{tabular}

$\mathrm{M}=$ male $; \mathrm{F}=$ female .

on our findings, future studies should focus heavily on melanoma, as all three $\beta$-AR receptors were most highly expressed in this cancer type. Supporting evidence for use of beta blockers in melanoma comes from several recent studies, whereby propranolol induces cell cycle arrest of melanoma cells [29], promotes anti-tumor immunity in a melanoma tumor model [30], and inhibits B16F10 melanoma xenografts at low doses [31]. Based on moderate levels of $\beta$-AR expression, other tumor types of interest for future study would be cancers of the esophagus, pancreas, kidney, and lung.

Overexpression of the $\beta$-AR receptors has been reported in breast cancer [17, 32], and our analysis uncovered multiple cancers which exhibited overexpression of $\beta-\mathrm{AR}$ receptors relative to their normal non-diseased tissue counterparts. These included urogenital/reproductive malignancies including breast, endometrium, ovarian, and urothelial cancer, as well 
as colon, lung, and thyroid cancer. It is possible that overexpression of the $\beta$-AR receptors could impart tumor sensitivity to beta blockade, though a previous report in breast cancer has shown no correlation between the levels of $\beta$-AR receptor mRNA in the tumor cells and sensitivity to propranolol [17]. Moreover, $\beta$-AR receptors are expressed at high levels in multiple endothelial cell types [2-5], yet exhibit clinically effective selectivity against vascular tumors $[10,19]$. Future preclinical and clinical studies should focus on clarifying this conundrum, and identifying reliable biomarkers of propranolol susceptibility in tumors.

The observations reported in this study will help to identify $\beta$-AR receptor positive tumors types so that future efforts evaluating the anti-cancer efficacy of beta blockade can be directed at the most promising targets. Furthermore, identification of tumor types with equivocal or non-detectable levels of $\beta$-AR receptors will guide future studies in avoiding tumors potentially nonresponsive to beta blockade.

\section{MATERIALS AND METHODS}

\section{Tissue microarrays}

Immunohistochemical staining (IHC) was performed on a clinically annotated tissue microarray (US Biomax \#MC5003b) containing formalin-fixed paraffinembedded tumor $(\mathrm{N}=389)$ and normal $(\mathrm{N}=100)$ tissues from human patients. Hematoxylin and eosin staining was used to confirm the classification of all tumors. The clinicopathological features of these tissues are shown in Table 2 .

\section{Immunohistochemistry}

Expression of the three $\beta$-AR receptors was evaluated using IHC for each tissue section. The primary antibodies used were anti- $\beta 1$-AR (Abbiotech \#250919; $1: 100$ dilution, citrate induced antigen retrieval), $\beta 2$ AR (Abbiotech \#251604; 1:100 dilution, citrate induced antigen retrieval), or $\beta 3$-AR (Abbiotech \#251434; 1:100 dilution, citrate induced antigen retrieval) under conditions previously reported $[16,17]$. The $\beta$-AR IHC reactions were visualized using HRP/DAB (ABC) Detection IHC Kit (Abcam \#ab64264). The staining intensity specifically in the normal and tumor cells was evaluated using the following criteria: $0=$ undetectable staining, $1=$ equivocal/ diffuse staining, 2 = weak staining, 3 = moderate staining, and $4=$ strong staining. The Mann-Whitney rank sum test was used to assess statistical analysis of $\beta$-AR expression between the normal and tumor tissues.

\section{Abbreviations}

$\beta$-AR - beta adrenergic receptor; $\beta$-AR1 beta adrenergic receptor $1 ; \beta$-AR2 - beta adrenergic receptor 2; $\beta$-AR3 - beta adrenergic receptor 3; cAMP - cyclic adenosine monophosphate; DAB 3,3'-diaminobenzidine; HRP - horse radish peroxidase; IHC - immunohistochemistry; NOS - nitric oxide synthase.

\section{Author contributions}

SLR - quantification of tissue IHC, generation of graphs, review and agree to final manuscript

CAN-quantification of tissue IHC, review and agree to final manuscript

$\mathrm{BAB}$ - statistical analysis tissue IHC, review and agree to final manuscript.

\section{ACKNOWLEDGMENTS}

We would like to thank Dolores Diaz and Jaime Rios from the Texas Tech University Health Sciences Center Pathology core for IHC staining of normal and cancer tissues.

\section{CONFLICTS OF INTEREST}

The authors have no conflicts of interest to disclose.

\section{FUNDING}

This study was supported by a grant from the Texas Emerging Technology Fund to BAB.

\section{REFERENCES}

1. Sorriento D, Trimarco B, Iaccarino G. Adrenergic mechanism in the control of endothelial function. Transl Med UniSa. 2011; 1: 213-28.

2. Taira N, Yabuuchi Y, Yamashita S. Profile of betaadrenoceptors in femoral, superior mesenteric and renal vascular beds of dogs. Br J Pharmacol. 1977; 59: 577-83.

3. Abdelrahman A, Tabrizchi R, Pang CC. Effects of beta 1- and beta 2-adrenoceptor stimulation on hemodynamics in the anesthetized rat. J Cardiovasc Pharmacol. 1990; 15: $720-8$.

4. Lands AM, Arnold A, McAuliff JP, Luduena FP, Brown TG, Jr. Differentiation of receptor systems activated by sympathomimetic amines. Nature. 1967; 214: 597-8.

5. Zwaveling J, Winkler Prins EA, Pfaffendorf $M$, van Zwieten PA. The influence of hyperthyroidism on betaadrenoceptor-mediated relaxation of isolated small mesenteric arteries. Naunyn Schmiedebergs Arch Pharmacol. 1996; 353: 438-44.

6. Insel PA, Hammond HK. Beta-adrenergic receptors in heart failure. J Clin Invest. 1993; 92: 2564. https://doi. org/10.1172/JCI116867.

7. McGraw DW, Forbes SL, Mak JC, Witte DP, Carrigan PE, Leikauf GD, Liggett SB. Transgenic overexpression 
of beta(2)-adrenergic receptors in airway epithelial cells decreases bronchoconstriction. Am J Physiol Lung Cell Mol Physiol. 2000; 279: L379-89.

8. Turki J, Green SA, Newman KB, Meyers MA, Liggett SB. Human lung cell beta 2-adrenergic receptors desensitize in response to in vivo administered beta-agonist. Am J Physiol. 1995; 269: L709-14.

9. Balligand JL. Beta3-adrenoreceptors in cardiovasular diseases: new roles for an "old" receptor. Curr Drug Deliv. 2013; 10: 64-6.

10. Leaute-Labreze C, Dumas de la Roque E, Hubiche T, Boralevi F, Thambo JB, Taieb A. Propranolol for severe hemangiomas of infancy. N Engl J Med. 2008; 358: 264951. https://doi.org/10.1056/NEJMc0708819.

11. Stiles J, Amaya C, Pham R, Rowntree RK, Lacaze M, Mulne A, Bischoff J, Kokta V, Boucheron LE, Mitchell DC, Bryan BA. Propranolol treatment of infantile hemangioma endothelial cells: A molecular analysis. Exp Ther Med. 2012; 4: 594-604. https://doi.org/10.3892/etm.2012.654.

12. Banavali S, Pasquier E, Andre N. Targeted therapy with propranolol and metronomic chemotherapy combination: sustained complete response of a relapsing metastatic angiosarcoma. Ecancermedicalscience. 2015; 9: 499. https://doi. org/10.3332/ecancer.2015.499.

13. Chow W, Amaya CN, Rains S, Chow M, Dickerson EB, Bryan BA. Growth Attenuation of Cutaneous Angiosarcoma With Propranolol-Mediated beta-Blockade. JAMA Dermatol. 2015; 151: 1226-9. https://doi. org/10.1001/jamadermatol.2015.2554.

14. Daguze J, Saint-Jean M, Peuvrel L, Cassagnau E, Quereux G, Khammari A, Dreno B. Visceral metastatic angiosarcoma treated effectively with oral cyclophosphamide combined with propranolol. JAAD Case Rep. 2016; 2: 497-9. https://doi.org/10.1016/j.jdcr.2016.10.005.

15. Pasquier E, Andre N, Street J, Chougule A, Rekhi B, Ghosh J, Philip DS, Meurer M, MacKenzie KL, Kavallaris M, Banavali SD. Effective Management of Advanced Angiosarcoma by the Synergistic Combination of Propranolol and Vinblastine-based Metronomic Chemotherapy: A Bench to Bedside Study. EBioMedicine. 2016; 6: 87-95. https://doi.org/10.1016/j. ebiom.2016.02.026.

16. Stiles JM, Amaya C, Rains S, Diaz D, Pham R, Battiste J, Modiano JF, Kokta V, Boucheron LE, Mitchell DC, Bryan BA. Targeting of beta adrenergic receptors results in therapeutic efficacy against models of hemangioendothelioma and angiosarcoma. PLoS One. 2013; 8: e60021. https://doi. org/10.1371/journal.pone.0060021.

17. Montoya A, Amaya CN, Belmont A, Diab N, Trevino R, Villanueva G, Rains S, Sanchez LA, Badri N, Otoukesh S, Khammanivong A, Liss D, Baca ST, et al. Use of non-selective beta-blockers is associated with decreased tumor proliferative indices in early stage breast cancer. Oncotarget. 2017; 8: 6446-6460. doi: https://doi. org/10.18632/oncotarget.14119.
18. Watkins JL, Thaker PH, Nick AM, Ramondetta LM, Kumar S, Urbauer DL, Matsuo K, Squires KC, Coleman RL, Lutgendorf SK, Ramirez PT, Sood AK. Clinical impact of selective and nonselective beta-blockers on survival in patients with ovarian cancer. Cancer. 2015; 121: 3444-51. https://doi.org/10.1002/cncr.29392.

19. Leaute-Labreze C, Hoeger P, Mazereeuw-Hautier J, Guibaud L, Baselga E, Posiunas G, Phillips RJ, Caceres H, Lopez Gutierrez JC, Ballona R, Friedlander SF, Powell J, Perek D, et al. A randomized, controlled trial of oral propranolol in infantile hemangioma. N Engl J Med. 2015; 372: 735-46. https://doi.org/10.1056/NEJMoa1404710.

20. Armaiz-Pena GN, Allen JK, Cruz A, Stone RL, Nick AM, Lin YG, Han LY, Mangala LS, Villares GJ, Vivas-Mejia P, Rodriguez-Aguayo C, Nagaraja AS, Gharpure KM, et al. Src activation by beta-adrenoreceptors is a key switch for tumour metastasis. Nat Commun. 2013; 4: 1403. https://doi. org/10.1038/ncomms 2413 .

21. Choy C, Raytis JL, Smith DD, Duenas M, Neman J, Jandial $\mathrm{R}$, Lew MW. Inhibition of beta2-adrenergic receptor reduces triple-negative breast cancer brain metastases: The potential benefit of perioperative beta-blockade. Oncol Rep. 2016; 35: 3135-42. https://doi.org/10.3892/or.2016.4710.

22. Hwa YL, Shi Q, Kumar SK, Lacy MQ, Gertz MA, Kapoor P, Buadi FK, Leung N, Dingli D, Go RS, Hayman SR, Gonsalves WI, Russell S, et al. Beta-blockers improve survival outcomes in patients with multiple myeloma: a retrospective evaluation. Am J Hematol. 2017; 92: 50-5. https:// doi.org/10.1002/ajh.24582.

23. Strosberg AD. Structure-function analysis of the three betaadrenergic catecholamine receptors. Psychopharmacol Ser. 1993; 10: 9-14.

24. Chisholm KM, Chang KW, Truong MT, Kwok S, West RB, Heerema-McKenney AE. beta-Adrenergic receptor expression in vascular tumors. Mod Pathol. 2012; 25: 1446-51. https://doi.org/10.1038/modpathol.2012.108.

25. Phillips JD, Zhang H, Wei T, Richter GT. Expression of beta-Adrenergic Receptor Subtypes in Proliferative, Involuted, and Propranolol-Responsive Infantile Hemangiomas. JAMA Facial Plast Surg. 2016. https://doi. org/10.1001/jamafacial.2016.1188.

26. Chatmethakul T, Bhat R, Alkaabi M, Siddiqui A, Peevy K, Zayek M. Infantile Hepatic Hemangioendothelioma: An Uncommon Cause of Persistent Pulmonary Hypertension in a Newborn Infant. AJP Rep. 2016; 6: e260-3. https://doi. org/10.1055/s-0036-1585578.

27. Filippi L, Tamburini A, Berti E, Perrone A, Defilippi C, Favre C, Calvani M, Della Bona ML, la Marca G, Donzelli G. Successful Propranolol Treatment of a Kaposiform Hemangioendothelioma Apparently Resistant to Propranolol. Pediatr Blood Cancer. 2016; 63: 1290-2. https://doi.org/ 10.1002/pbc.25979.

28. Uppuluri R, Kumar V, Munirathnam D, Doss H, Ramachandrakurup S, Subburaj D, Raj R. Kaposiform Hemangioendothelioma in a 3 Months Old Infant. Indian 
J Hematol Blood Transfus. 2016; 32: 370-1. https://doi. org/10.1007/s12288-016-0674-y.

29. Zhou C, Chen X, Zeng W, Peng C, Huang G, Li X, Ouyang Z, Luo Y, Xu X, Xu B, Wang W, He R, Zhang $\mathrm{X}$, et al. Propranolol induced $\mathrm{G} 0 / \mathrm{G} 1 / \mathrm{S}$ phase arrest and apoptosis in melanoma cells via AKT/MAPK pathway. Oncotarget. 2016; 7: 68314-27. https://doi.org/10.18632/ oncotarget. 11599.

30. Jean Wrobel L, Bod L, Lengagne R, Kato M, PrevostBlondel A, Le Gal FA. Propranolol induces a favourable shift of anti-tumor immunity in a murine spontaneous model of melanoma. Oncotarget. 2016; 7: 77825-37. https:// doi.org/10.18632/oncotarget.12833.
31. Maccari S, Buoncervello M, Rampin A, Spada M, Macchia D, Giordani L, Stati T, Bearzi C, Catalano L, Rizzi R, Gabriele L, Marano G. Biphasic effects of propranolol on tumour growth in B16F10 melanoma-bearing mice. Br J Pharmacol. 2017; 174: 139-49. https://doi.org/10.1111/ bph.13662.

32. Gargiulo L, Copsel S, Rivero EM, Gales C, Senard JM, Luthy IA, Davio C, Bruzzone A. Differential beta(2)adrenergic receptor expression defines the phenotype of non-tumorigenic and malignant human breast cell lines. Oncotarget. 2014; 5: 10058-69. https://doi.org/10.18632/ oncotarget. 2460 . 